\title{
МЕТОДИ ОЦІНКИ ІННОВАЦІЙНОЇ РЕФЛЕКСІЇ ПІДПРИСМСТВ ЯК ОСНОВА РОЗРОБКИ РАЦІОНАЛЬНИХ УПРАВЛІНСЬКИХ СТРАТЕГІЙ
}

\author{
Колещук О.Я., к.е.н., доцент (НУ «Львівська політехніка»)
}

В статті визначено, що сучасні умови господарювання потребують підвищеної уваги до проблем формування стратегічного управління інноваційністю підприємств, базуючись, перш за все на ефективному впровадженні інноваційності для розвитку підприємств, щзо впливає на підвищення конкурентоспроможності підприємств шляхом продукування та впровадження раціональних стратегій.

Запропоновано систему приниипів для формування комплексу методів оцінки інноваційної рефлексії. Результати проведеного аналізу економічної літератури надало можливість виокремити та сформувати порівняльну характеристику методів очінки інноваційної рефлексії.

Визначено, щзо для визначення необхідної методичної бази оиінки інноваційної рефлексї підприємств різного типу та масштабу з метою формування управлінських стратегій, необхідно розглянути характеристики кожного методу з точки зору аналітичної інформачії, прийнятих критеріїв аналізу, підходів до обробки, інтерпретації результатів тощчо.

Ключові слова: підприсмства; стратегічне управління інноваційністю підприємств; інноваційна рефлексія; методи; система принципів.

\section{МЕТОДЫ ОЦЕНКИ ИННОВАЦИОННОЙ РЕФЛЕКСИИ КОМПАНИЙ КАК ОСНОВА РАЗРАБОТКА РАЦИОНАЛЬНЫХ УПРАВЛЕНЧЕСКИХ СТРАТЕГИЙ}

\author{
Колещук О.Я., к.э.н., доцент (НУ «Львовская политехника»)
}

В статье определено, что современные условия хозяйствования требуют повышенного внимания к проблемам формирования стратегического управления инновачионностью предприятий, основываясь, прежде всего на эффективном внедрении инновационности для развития предприятий, влияет на повышение конкурентоспособности предприятий путем выработки и внедрения рациональных стратегий.

Предложена система принципов для формирования комплекса методов оценки инновационной рефлексии. Результаты проведенного анализа экономической литературы позволили выделить и сформировать сравнительную характеристику методов оченки инновачионной рефлексии.

Определено, что для определения необходимой методической базы оценки инновационной рефлексии предприятий различного типа и масштаба с иелью формирования управленческих стратегий, необходимо рассмотреть характеристики каждого метода с точки зрения аналитической информачии, принятых критериев анализа, подходов к обработке, интерпретации результатов и тому подобное. 
Ключевые слова: предприятия; стратегическое управление инновационностью предприятий; инновационная рефлексия; методы; система принципов.

\title{
METHODS FOR EVALUATING INNOVATIVE REFLECTION COMPANIES AS THE BASIS FOR THE DEVELOPMENT RATIONAL MANAGEMENT STRATEGIES
}

\author{
Koleshchuk O., (PhD, Associate Professor \\ (Lviv Polytechnic National University)
}

The article determines that modern business conditions require increased attention to the problems forming strategic management enterprise innovativeness, based primarily on the effective implementation innovation for enterprise development, affecting the competitiveness enterprises through the development and implementation rational strategies.

In modern conditions the development the market environment from the perspective increasing attention to the active implementation innovation in the strategic orientation enterprise development, it becomes necessary to determine the readiness enterprises for innovation. It should be noted that assessment is a rather important stage in the process forming strategic management enterprise innovativeness. It is based on an array information and consists in determining the possible consequences implementing the chosen strategy.

The essence assessing the readiness enterprises for innovation is to determine the advantages and disadvantages competing enterprises by indicators - indicators that should be determined at the stage identification of key indicators the degree of innovative reflection.

A system principles is proposed for the formation a set methods for evaluating innovative reflection. The results the analysis economic literature made it possible to isolate and form a comparative characteristic the methods for assessing innovative reflection.

It is determined that in order to determine the necessary methodological basis for assessing the innovative reflection enterprises various types and sizes in order to form managerial strategies, it is necessary to consider the characteristics each method in terms analytical information, accepted analysis criteria, processing approaches, interpretation results, and the like.

Keywords: enterprises; strategic management enterprise innovation; innovative reflection; methods system principles.

Постановка проблеми. Сучасні умови господарювання потребують підвищеної уваги до проблем формування стратегічного управління інноваційністю підприємств, базуючись, перш за все, на ефективному впровадженні інноваційності для розвитку підприємств, що впливає на підвищення їх конкурентоспроможності шляхом продукування та впровадження раціональних стратегій.

В умовах турбулентного конкурентного середовища ключовою метою діяльності підприємства $\epsilon$ ефективне впровадження інноваційності на основі поєднання економічного та стратегічного аспектів управління підприємствами, є підгрунтям довгострокової перспективи реалізації 
цілей, завдань та отримання бажаного результату. Для цього необхідно формувати оцінки готовності підприємств до інноваційності за допомогою використання методів, що дозволить стратегічно управляти інноваційністю та порівнювати 3 підприємствами-конкурентами.

Аналіз сучасної практики діяльності підприємств свідчить про те, що досягнення високих результатів у довгостроковій перспективі можливе лише за систематичного i цілеспрямованого процесу впровадження інноваційності, націленого на пошук потенційних можливостей. Це визначає специфічний стиль господарювання, в основу якого покладено орієнтацію на креативність, евристичність, конструктивність, емпіричність і цілеспрямовану стратегічну діяльність.

Аналіз останніх досліджень та публікацій. Питання, пов'язані 3 формуванням оцінки готовності підприємств до інноваційності є об'єктом дослідження значної кількості науковців, зокрема, I. Ансоффа [1], В. Винокурова [2], В. Диканя [3], Л. Москаленко [4], М. Кизима [6], М. Потрера [6], В. Пономаренка [5], В. Прохорової [7, 8], О. Тридіда [5], А. Томпсона [9], О. Хринюк [4] та ін.

Виділення невирішених частин загальної проблеми. Доцільно зауважити, що сьогодні проблема формування стратегічного управління інноваційністю підприємств набула особливого значення, оскільки ринок потребує активних нововведень.В свою чергу це потребує залучення інвестиційних ресурсів шляхом продукування та впровадження раціональних стратегій.

Метою статті $\epsilon$ формування методів оцінки інноваційної рефлексії підприємств як основа розробки раціональних управлінських стратегій.

Викладення основного матеріалу дослідження. В сучасних умовах розвитку ринкового середовища 3 позиції підвищення уваги до активного впровадження інноваційності у стратегічній орієнтованості розвитку підприємств, виникає необхідність визначати оцінки готовності підприємств до інноваційності. Необхідно зазначити, що оцінка $\epsilon$ досить важливим етапом процесу формування стратегічного управління інноваційністю підприємств. Вона грунтується на масиві інформації й полягає у визначенні можливих наслідків реалізації обраної стратегії.

Суттєвість оцінки готовності підприємств до інноваційності полягає у визначенні переваг i недоліків підприємств-конкурентів за індикаторами показниками, що мають бути визначені на етапі ідентифікації ключових індикаторів ступеня інноваційної рефлексії.

Необхідно порівнювати діяльність підприємства та визначати його рівень готовності до сприйняття інноваційності, завдяки чому визначається не тільки позиція оцінюваного підприємства, а й кількісний розрив у досягнутих значеннях, порівняння об'єкту оцінки 3 групою підприємств-конкурентів та дозволяє визначити підприємство-лідера 3 досліджуваної групи і аутсайдерів групи, які посіли останні місця за рівнем інноваційної рефлексії. Для вибору комплексу методів оцінки рівня інноваційної рефлексії необхідно використовувати наступні принципи, що наведені на рис. 1.

Для ефективного використання обгрунтованого методу необхідним $\epsilon$ наявність якісного інформаційного забезпечення 3 урахуванням мінливості зовнішнього середовища сучасних підприємств.

У стратегічному аналізі використовується ряд загальнонаукових прийомів: аналіз, синтез, індукція, дедукція, аналогія, спостереження, порівняння, моделювання, абстрагування, конкретизація, системний аналіз, оцінка, класифікація та ін. 


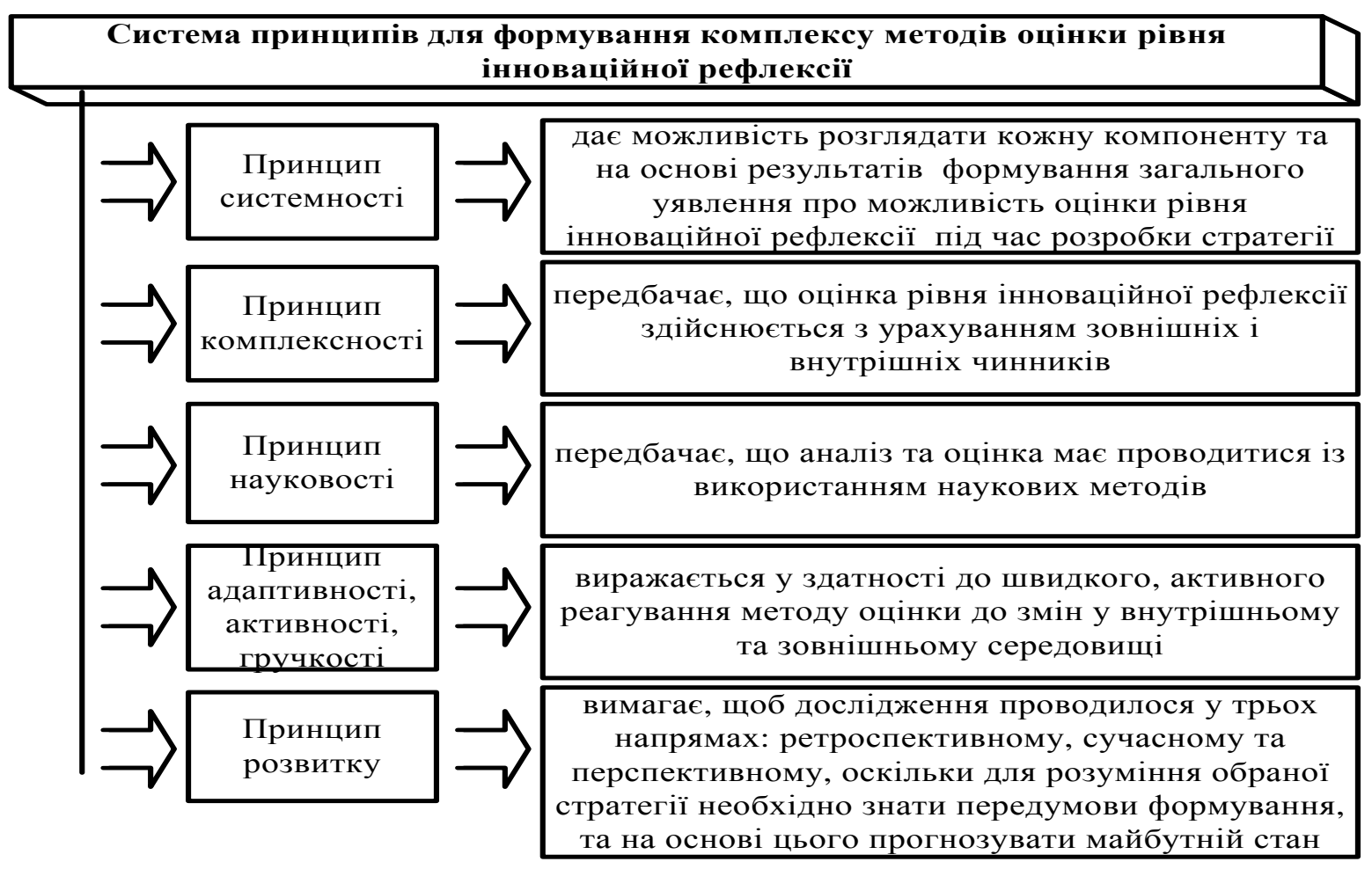

Рис. 1. Система принципів для формування комплексу методів оцінки інноваџійної рефлексіі

\begin{tabular}{lcc}
\multicolumn{3}{c}{ Результати аналізу економічної } \\
літератури & надало & можливість \\
виокремити & та & сформувати
\end{tabular}

Результати аналізу економічної виокремити порівняльну оцінки (табл. 1). характеристику методів інноваційної рефлексії

Таблиия 1

Порівняльна характеристика методів оиінки інноваційної рефлексії

\begin{tabular}{|c|c|c|c|}
\hline Метод & $\begin{array}{c}\text { Особливості } \\
\text { застосування }\end{array}$ & Переваги & Недоліки \\
\hline 1 & 2 & 3 & 4 \\
\hline $\begin{array}{l}\text { Метод } \\
\text { ситуаційног } \\
0 \quad \text { SWOT- } \\
\text { аналізу }\end{array}$ & $\begin{array}{lrr}\epsilon & \text { першим } & \text { етапом } \\
\text { стратегічного } & \\
\text { планування } & \end{array}$ & $\begin{array}{l}\text { Систематизація знань } \\
\text { про внутрішні й } \\
\text { зовнішні фактори, що } \\
\text { впливають на процес } \\
\text { стратегічного } \\
\text { планування } \\
\text { Визначення } \\
\text { конкурентних переваг } \\
\text { та фа формування } \\
\text { стратегічних } \\
\text { пріоритетів } \\
\text { Періодична діагностика } \\
\text { ринку та ресурсів } \\
\text { фірми та }\end{array}$ & $\begin{array}{l}\text { Суб’єктивність вибору } \\
\text { та ранжування факторів } \\
\text { навколишнього } \\
\text { внутрішнього } \\
\text { середовища } \\
\text { Слабка підтримка } \\
\text { прийняття конкретних } \\
\text { управлінських рішень } \\
\text { Погана адаптація до } \\
\text { середовища, що } \\
\text { постійно змінюється }\end{array}$ \\
\hline
\end{tabular}


Пробовження табл. 1

\begin{tabular}{|c|c|c|c|}
\hline 1 & 2 & 3 & 4 \\
\hline $\begin{array}{l}\text { Метод РIMS } \\
\text { (Profit Impact } \\
\text { of Marketing } \\
\text { Strategy) }\end{array}$ & $\begin{array}{l}\text { передбачає визначення } \\
\text { кількісних } \\
\text { закономірностей впливу } \\
\text { чинників виробництва } \\
\text { на кінцеві результати } \\
\text { діяльності підприємства } \\
\text { (прибуток, } \\
\text { рентабельність, обсяги } \\
\text { продажу), виходячи } 3 \\
\text { аналізу емпіричного } \\
\text { матеріалу про досвід } \\
\text { функціонування значної } \\
\text { кількості промислових } \\
\text { підприємств }\end{array}$ & $\begin{array}{lr}\text { Висока придатність для } \\
\text { вироблення стратегій; } \\
\text { можливість деталізації } \\
\text { стратегічних проблем } \\
\text { підприємства; є основою } \\
\text { для аналізу взаємодії } \\
\text { між різними напрямами } \\
\text { діяльності і різних } \\
\text { стадій розвитку кожного } \\
\text { напряму діяльності }\end{array}$ & 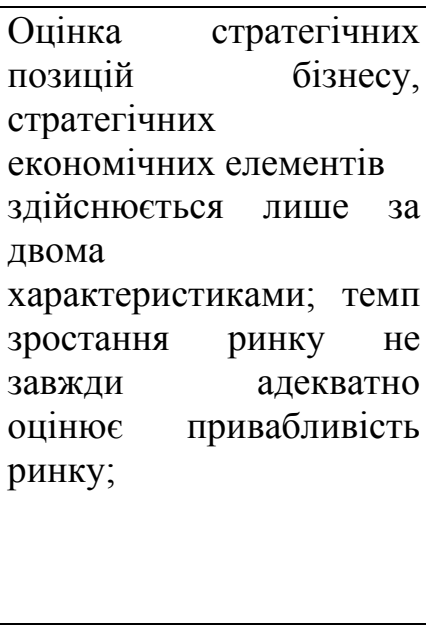 \\
\hline $\begin{array}{l}\text { метод GAP- } \\
\text { аналіз }\end{array}$ & $\begin{array}{l}\text { метод аналізу первинної } \\
\text { iнформації, } \\
\text { стратегічне розходження } \\
\text { між бажаним - чого } \\
\text { підприємство } \\
\text { досягнути воче } \\
\text { розвитку своєму } \\
- \text { ч рего фактично може } \\
\text { досягти підприємство, } \\
\text { не змінюючи свою } \\
\text { нинішню політику. } \\
\end{array}$ & $\begin{array}{lr}\text { простота методу, } \\
\text { також те, що за } \\
\text { допомогою } \\
\text { можна } \\
\begin{array}{l}\text { напрямки удосконолалення } \\
\text { інноваційної політики }\end{array}\end{array}$ & 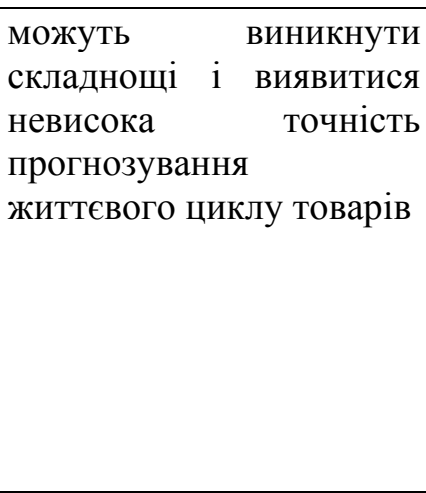 \\
\hline $\begin{array}{l}\text { Модель } \\
\text { Shell/DPM) }\end{array}$ & $\begin{array}{l}\text { є своєрідним розвитком } \\
\text { ідеї стратегічного } \\
\text { позиціонування бізнесу, } \\
\text { закладеної в модель БКГ }\end{array}$ & \begin{tabular}{lr}
\multicolumn{3}{l}{ Застосування стратегії } \\
системи якісних і \\
кількісних показників \\
дозволяє обгрунтувати \\
стратегічний \\
забезпечує мобір; \\
підтримки балансу між \\
надлишком і дефіцитом \\
коштів шляхом розвитку \\
перспективних СП \\
підприємства; \\
позиціонування \\
різних фазах ЖЦП
\end{tabular} & $\begin{array}{lr}\text { Застосування } \\
\text { (здебільшого) } \\
\text { капіталомістких галузях } \\
\text { промисловості; } \\
\text { відсутність } \\
\text { відбору критерію } \\
\text { оцінки показників } \\
\text { матриці; суб'єктивність } \\
\text { визначення } \\
\text { коефіцієнтів для оцавінки } \\
\text { показників; неточність } \\
\text { результатів порівняння } \\
\text { СЗГ, які належать до } \\
\text { різних галузей } \\
\end{array}$ \\
\hline Метод PIMS & $\begin{array}{l}\text { передбачас визначення } \\
\text { кількісних } \\
\text { закономірностей впливу } \\
\text { чинників виробництва } \\
\text { на кінцеві результати } \\
\text { діяльності організацій } \\
\text { (рентабельність, } \\
\text { прибуток), виходячи } 3 \\
\text { аналізу емпіричного } \\
\text { матеріалу про досвід } \\
\text { функціонування значної } \\
\text { кількості промислових } \\
\text { організацій }\end{array}$ & $\begin{array}{lr}\text { Завдяки } & \text { використанням } \\
\text { емпіричного } & \text { матеріалу } \\
\text { можна скоротити розрив } & \text { між } \\
\text { (теоретичним) } & \text { абстрактним } \\
\text { конкретним } & \text { (Модель } \\
\text { дозволяє } & \text { виміряти } \\
\text { відносну якість продукту }\end{array}$ & $\begin{array}{l}\text { Об'єктом дослідження } \\
\text { здебільшого } \\
\text { організації, які вже } \\
\text { завоювали певні позиції } \\
\text { на ринку, тому цей } \\
\text { метод не можна } \\
\text { застосовувати } \\
\text { високотехнологічних } \\
\text { галузях }\end{array}$ \\
\hline
\end{tabular}

Вісник економіки транспорту і промисловості № 68, 2019 
Пробовження табл.1

\begin{tabular}{|c|c|c|c|}
\hline 1 & 2 & 3 & 4 \\
\hline Метод LOTS & $\begin{array}{l}\text { передбачає детальне, } \\
\text { послідовне обговорення } \\
\text { ряду проблем бізнесу на } \\
\text { piзних рівнях і різній } \\
\text { мірі складності: від } \\
\text { корпоративної місї } \\
\text { підприємства в цілому } \\
\text { до індивідуального } \\
\text { проекту у усередині } \\
\text { підприємства }\end{array}$ & & \\
\hline Метод ADL & $\begin{array}{l}\text { Ï̈̈ призначення полягає в } \\
\text { тому, щоб забезпечити } \\
\text { менеджерів оригінальної } \\
\text { методики стратегічного } \\
\text { аналізу і планування, } \\
\text { дати їм по можливості } \\
\text { потужний інструмент } \\
\text { аналізу портфельних } \\
\text { стратегій для визначення } \\
\text { розумної диверсифікації } \\
\text { діяльності } \\
\text { багатогалузевої } \\
\text { організації, який можна } \\
\text { було б використовувати } \\
\text { як на корпоративному } \\
\text { рівні, так і на рівні } \\
\text { окремих господарських } \\
\text { ланок. }\end{array}$ & 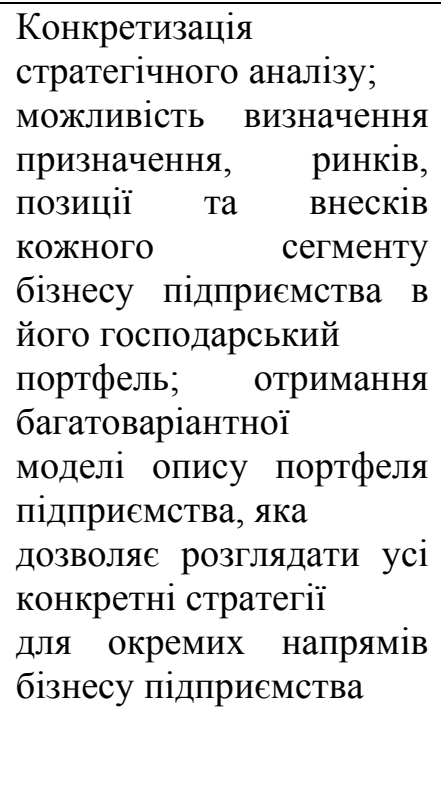 & 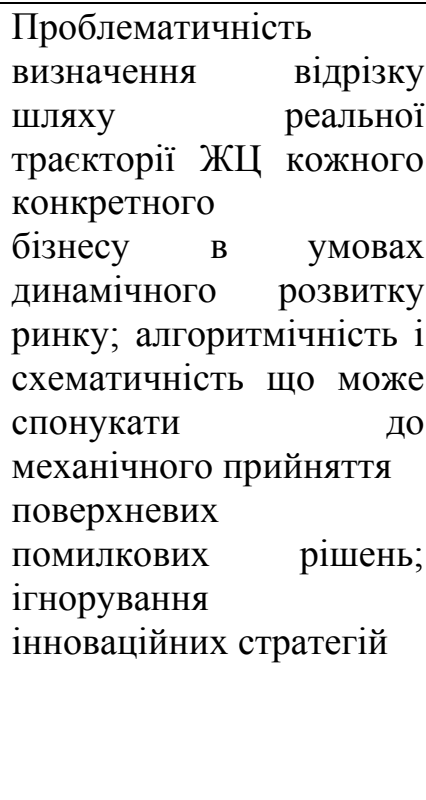 \\
\hline SNW -аналіз & $\begin{array}{lr}\text { аналіз } & \text { сильних, } \\
\text { нейтральних, } & \text { слабких } \\
\text { сторін підприємства }\end{array}$ & 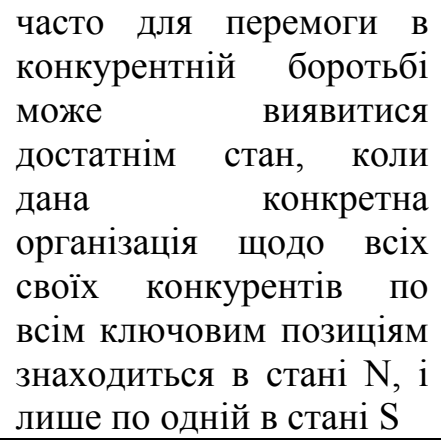 & $\begin{array}{l}\text { відсутність чітких та } \\
\text { конкретних } \\
\text { рекомендацій }\end{array}$ \\
\hline $\begin{array}{l}\text { SPACE- } \\
\text { аналіз }\end{array}$ & $\begin{array}{l}\text { метод, призначений для } \\
\text { аналізу позиції на ринку } \\
\text { i вибору оптимальної } \\
\text { стратегії для середніх і } \\
\text { малих фірм }\end{array}$ & $\begin{array}{lr}\text { дає змогу } & \text { здійснити } \\
\text { оцінку } & \text { сильних та } \\
\text { слабких } & \text { сторін } \\
\text { діяльності } & \text { невеликих } \\
\text { підприємств } & \text { за } \\
\text { відповідними } & \text { групами } \\
\text { критеріїв } & \\
\text { r }\end{array}$ & $\begin{array}{l}\text { залучення експертів із } \\
\text { числа внутрішніх чи } \\
\text { зовнішніх консультантів }\end{array}$ \\
\hline
\end{tabular}


Пробовження табл. 1

\begin{tabular}{|c|c|c|c|}
\hline 1 & 2 & 3 & 4 \\
\hline $\begin{array}{l}\text { Модель } \\
\text { МакКінсі }\end{array}$ & $\begin{array}{lr}\text { використання } & \text { вагових } \\
\text { коефіцієнтів } & \text { при } \\
\text { побудові моделі і облік } \\
\text { трендів розвитку галузі. }\end{array}$ & $\begin{array}{lr}\text { Широка } & \text { сфера } \\
\text { застосування } & \text { порівняно } \\
3 \quad \text { матрицею } & \text { BCG; } \\
\text { диференційована оцінка } \\
\text { підприємства; детальний } \\
\text { аналіз } \\
\text { привабливості ринку і за } \\
\text { рахунок збільшення } \\
\text { кількості } \\
\text { факторів }\end{array}$ & $\begin{array}{lr}\text { Не враховується } \\
\text { можливість } \quad \text { активного } \\
\text { впливу підприємства на } \\
\text { зовнішнє оточення; }\end{array}$ \\
\hline $\begin{array}{l}\text { Модель } \\
\text { М. Портера }\end{array}$ & 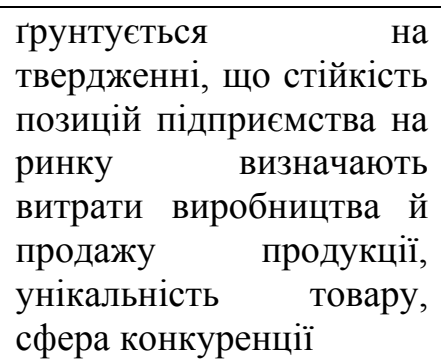 & $\begin{array}{l}\text { Дає } \quad \text { можливість } \\
\text { визначити всебічний } \\
\text { вплив зовнішніх сил на } \\
\text { конкуренцію }\end{array}$ & $\begin{array}{l}\text { За наявності особливої } \\
\text { позиції на ринку, відомо } \\
\text { як досягнути переваги } \\
\text { над конкурентами; } \\
\text { концентрація тільки } \\
\text { одному виді стратегії }\end{array}$ \\
\hline $\begin{array}{l}\text { Модель } \\
\text { ғакопиченого } \\
\text { досвіду }\end{array}$ & 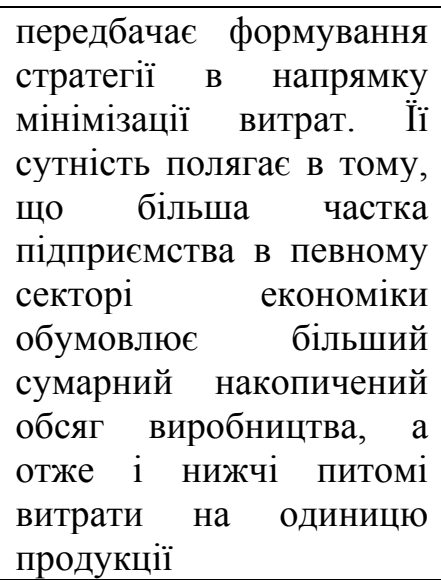 & $\begin{array}{lr}\text { дозволяє } & \text { оцінити } \\
\text { закономірність } & \\
\text { формування } & \text { затрат } \\
\text { залежно від } & \text { питомого } \\
\text { обсягу виробництва, дає } \\
\text { можливість порівняти } \\
\text { витрати конкурентів, які } \\
\text { діють на одному і тому } \\
\begin{array}{lr}\text { ж ринку, і виявити } \\
\text { необхідність } \\
\text { стратегії }\end{array} \\
\end{array}$ & $\begin{array}{lr}\text { Для секторів економіки і } \\
\text { ринків } 3 \text { низькими } \\
\text { темпами } \\
\text { збільшення } \\
3 \quad \text { виробвитету } \\
3 \text { метою } \\
\text { витрат може пришення } \\
\text { перевиробництва } \\
\text { продукту. }\end{array}$ \\
\hline Бенчмаркінг & $\begin{array}{l}\text { Спосіб оцінки стратегій і } \\
\text { цілей роботи } \\
\text { порівнянні } \\
\text { першокласними } \\
\text { підприємствами, для } \\
\text { того, щоб гарантувати } \\
\text { довгострокове } \\
\text { перебування на ринку }\end{array}$ & 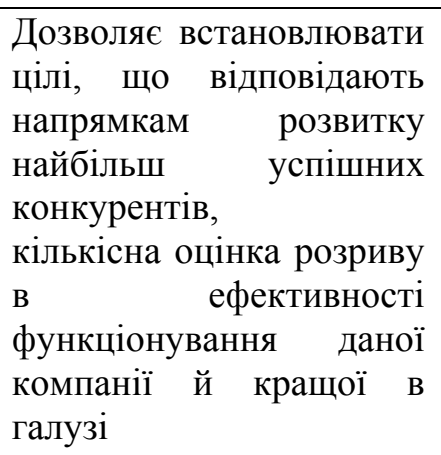 & $\begin{array}{lr}\text { Складність } & \text { вибору } \\
\text { партнерів } & \text { для } \\
\text { порівняння } & \text { основних } \\
\text { процесів, різні } & \text { методики } \\
\text { порівняння } & \text { та } \\
\text { трактування } & \text { ключових } \\
\text { параметрів } & \\
\text { успіху 3 } 3 \text { точки } & \text { зору } \\
\text { експертів та } & \text { керівників } \\
\text { підприємств } & \end{array}$ \\
\hline $\begin{array}{l}\text { Методи } \\
\text { теорії ігор }\end{array}$ & $\begin{array}{l}\text { Математичний апарат, } \\
\text { що розглядає конфліктні } \\
\text { ситуації, а також } \\
\text { ситуації спільних дій }\end{array}$ & $\begin{array}{lr}\text { Дозволяє } & \text { приймати } \\
\text { рішення } & \text { за } \\
\text { невизначеності } & \text { умов } \\
\text { ризику } & \text { та } \\
\end{array}$ & $\begin{array}{l}\text { Вимагає необхідність } \\
\text { володіння методами та } \\
\text { технологіями, за } \\
\text { допомогою яких можна } \\
\text { звести реальну задачу до } \\
\text { теоретичної }\end{array}$ \\
\hline
\end{tabular}


Пробовження табл. 1

\begin{tabular}{|c|c|c|c|}
\hline 1 & 2 & 3 & 4 \\
\hline $\begin{array}{l}\text { Матричні } \\
\text { методи }\end{array}$ & $\begin{array}{l}\text { Метод якісного аналізу } \\
\text { позиціонування } \\
\text { підприємства } \\
\text { конкурентному } \\
\text { середовищі }\end{array}$ & $\begin{array}{lr}\text { Дозволяє } & \text { визначити } \\
\text { конкурентну } & \text { позицію } \\
\text { підприємства } & \text { на } \\
\text { відносно } \\
\text { учасників } & \text { iнших } \\
& \end{array}$ & $\begin{array}{lr}\text { Необхідність } & \text { значних } \\
\text { об’ємів } & \text { вхідної } \\
\text { інформації } & \end{array}$ \\
\hline $\begin{array}{l}\text { Коефіцієнтні } \\
\text { методи }\end{array}$ & $\begin{array}{l}\text { Визначення відносних } \\
\text { характеристик } \\
\text { комплексного характеру } \\
\text { на основі сформованого } \\
\text { набору показників }\end{array}$ & $\begin{array}{l}\text { Оцінка } \\
\text { конкурентоспроможност } \\
\text { і на конкретному ринку } \\
\text { на основі детального } \\
\text { вивчення виробничих, } \\
\text { збутових, фінансових } \\
\text { можливостей } \\
\text { підприємства, } \\
\text { організації } \\
\text { управління }\end{array}$ & $\begin{array}{l}\text { Обмежене } \\
\text { переважно коло, } \\
\text { показників, відсутність } \\
\text { належної систематизації } \\
\text { запропонованих } \\
\text { показників }\end{array}$ \\
\hline $\begin{array}{l}\text { Метод } \\
\text { економіко- } \\
\text { математично } \\
\text { го } \\
\text { моделюванн } \\
\text { я }\end{array}$ & 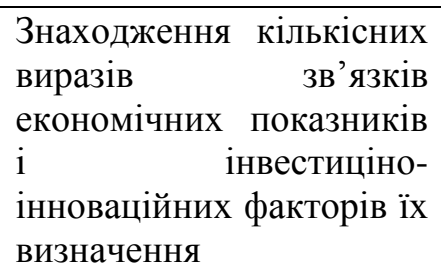 & $\begin{array}{l}\text { Дозволяе урахувати } \\
\text { вплив зовнішніх та } \\
\text { внутрішніх чинників при } \\
\text { прогнозуванні }\end{array}$ & $\begin{array}{lrr}\text { Значні часові } & \text { затрати, } \\
\text { значні обсяги } & \text { вихідної } \\
\text { інформації } & \text { для } \\
\text { максимально } & \text { точного } \\
\text { моделювання } & \end{array}$ \\
\hline $\begin{array}{l}\text { Методи } \\
\text { експертних } \\
\text { оцінок }\end{array}$ & $\begin{array}{l}\text { Надання обгрунтованої } \\
\text { експертної оцінки }\end{array}$ & $\begin{array}{l}\text { Висока ступінь } \\
\text { адаптивності а гнучкості } \\
\text { результатів }\end{array}$ & $\begin{array}{ll}\text { Суб’єктивізм } & \text { експертної } \\
\text { оцінки, } & \text { зниження } \\
\text { достовірності } & \\
\text { результатів } & \end{array}$ \\
\hline
\end{tabular}

При концентрації уваги на одному 3 розрахункових методів необхідно ураховувати ряд ключових вимог при відборі показників, які будуть придатні для подальшого розрахунку та відображення ефективності формування стратегічного управління інноваційністю підприємств.

Кожному підприємству 3 метою завоювання нових ринків необхідно забезпечувати та підтримувати процес інноваційністі, розробляти та впроваджувати механізми стратегічного управління нею. Керівництву підприємства необхідно займати активну позицію щодо створення рамкових умов реалізації процесу інноваційності, інакше підприємство неминуче почне втрачати свою ринкову вартість під впливом конкуренції та непередбачуваних зовнішніх і внутрішніх обставин.

$$
\text { Формування стратегічного }
$$

управління інноваційністю підприємств включає загальні принципи, на основі яких керівники підприємства можуть приймати взаємопов'язані рішення, покликані забезпечити координоване i впорядковане досягнення цілей у довгостроковому періоді.

Висновки. В сучасних умовах очевидна важливість вирішення таких питань, як вибір методів оцінки інноваційної рефлексії підприємств. Найчастіше перше завдання вирішується за допомогою залучення в аналіз все більшого числа показників і вибору 3 їх числа таких, які в значній мірі відображають результативність роботи 
підприємства. Однак при збільшенні кількості показників знижується здатність сприйняття інформації, а отже, ускладнюється процес прийняття рішень. До того ж виникає необхідність визначення значущості показників, їх ролі в досягненні ефективної діяльності.

Діяльність підприємства здійснюється під впливом зовнішнього і внутрішнього середовища тому аналіз оцінки інноваційної рефлексії підприємств дозволяє виявити резерви збільшення як всередині, так і зовні з метою формування конкурентних стратегій.

Таким чином, для визначення необхідної методичної бази оцінки інноваційної рефлексії підприємств різного типу та масштабу 3 метою формування управлінських стратегій, необхідно розглянути характеристики кожного методу з точки зору аналітичної інформації, прийнятих критеріїв аналізу, підходів до обробки, інтерпретації результатів тощо.

\section{ПЕРЕЛІК ВИКОРИСТАНИХ ДЖЕРЕЛ}

1. Ансофф И. Стратегическое управление: сокр. пер. с англ. / науч. ред. и авт. предисл. Л. И. Евенко. Москва: Экономика, 1989. - 519 с.

2. Винокуров В. А. Оганизация стратегического управления на предприятии. Москва: Центр экономики и маркетинга, 1996. - 458 с.

3. Дикань В. Л. Теорія й методи стратегічного управління / В. Л. Дикань // Збірник наукових праць Державного економіко - технологічного університету транспорту. Серія «Економіка i управління». - 2008. - № 12. - С. 214 - 217.

4. Москаленко Л. А., Хринюк О. С. Методи антикризового управління підприємством // Актуальні проблеми економіки та управління. 2011. Вип. 5. C. $114-117$.

5. Пономаренко В. С., Тридід О. М., Кизим М. О. Стратегія розвитку підприємства в умовах кризи: монографія. Харків: ВД «ІНЖЕК», 2003. - 328 с.

6. Портер М. Стратегія конкуренції. Київ: Основи, 1998. - 390 с.

7. Прохорова В. В. Проценко В. М., Чобіток В. I. Формування конкурентної стратегії підприємств на засадах інноваційно-спрямованого інвестування: монографія. Харків: Українська інженернопедагогічна академія, 2015. - 291 с.

8. Прохорова В.В., Чобіток В. I. Управління потенціалом конкурентоспроможності підприємств на засадах контролінгу : монографія. Харків: Українська інженерно-педагогічна академія, 2012. - 278 с.

9. Томпсон А. А., Стрикленд А. Дж. Стратегический менеджмент. Концепции и ситуации: учеб. для вузов: пер. 9-го англ. изд. Москва: ИНФРА-М, 2000. - 411 с.

10. Фатхутдинов Р. А. Конкурентоспособность: экономика, стратегия, управление. Москва: ИНФРАM, 2000. - 312 c.

11. Шершньова 3. Є. Стратегічне управління: підручник. 2-ге вид., перероб. та доп. Київ: Київський національний економічний університет, 2004. - 699 с.

\section{REFERENCE}

1. Ansoff I. (1989) Strategicheskoe upravlenie: sokr. per. $s$ angl. [Strategic Management: Soc. trans. with English] / nauch. red. i avt. predisl. L. I. Evenko. Moskva: Ekonomika, 519 p.

2. Vinokurov V. A. (1996) Oganizatsiya strategicheskogo upravleniya na predpriyatii [Organization of strategic management at the enterprise] . Moskva: Tsentr ekonomiki i marketinga, $458 \mathrm{p}$

3. Dykanj V. L. (2008) Teorija j metody strateghichnogho upravlinnja [Theory and methods of strategic management]. Collection of scientific works of the State Economic and Technological University of Transport. Economics and Management Series. no 12. - pp. 214 - $217 .$. 
4. Moskalenko L. A., Khrynjuk O. S. (2011) Metody antykryzovogho upravlinnja pidpryjemstvom [Methods of crisis management of enterprise]. Actual problems of economy and management.. Iss. 5. P. 114 117.

5. Ponomarenko V. S., Trydid O. M., Kyzym M. O. (2003) Strateghija rozvytku pidpryjemstva $v$ umovakh kryzy: monoghrafija [Strategy of enterprise development in crisis conditions: monograph]. Kharkiv: VD «INZhEK», $328 \mathrm{p}$.

6. Porter M. (1998) Strateghija konkurenciji [Competition strategy]. Kyjiv: Osnovy, 390 p.

7. Prokhorova V. V. Procenko V. M., Chobitok V. I. (2015) Formuvannja konkurentnoji strateghiji pidpryjemstv na zasadakh innovacijno-sprjamovanogho investuvannja: monoghrafija [Formation of the competitive strategy of enterprises on the basis of innovatively directed investment: a monograph]. Kharkiv: inzhenerno-pedaghoghichna $291 \mathrm{pp}$.
8. Prokhorova V.V., Chobitok V. I. (2012) Upravlinnja potencialom konkurentospromozhnosti pidpryjemstv na zasadakh kontrolinghu : monoghrafija [Management of the potential of competitiveness of enterprises on the basis of controlling: a monograph]. Kharkiv: Ukrajinsjka inzhenerno-pedaghoghichna akademija, $278 \mathrm{pp}$.

9. Tompson A. A., Striklend A. Dzh. (2000) Strategicheskiy menedzhment. Kontseptsii $i$ situatsii: ucheb. dlya vuzov [Strategic Management. Concepts and situations]: per. 9-go angl. izd. Moskva: INFRA-M, $411 \mathrm{pp}$.

10. Fatkhutdinov R. A. (2000) Konkurentosposobnost': ekonomika, strategiya, upravlenie [Competitiveness: Economy, Strategy, Management]. Moskva: INFRA-M, $312 \mathrm{pp}$.

11. Shershnjova Z. Je. (2004) Strateghichne upravlinnja: pidruchnyk. 2-ghe vyd., pererob. ta dop [Strategic Management: A Textbook]. Kyjiv: Kyjivsjkyj nacionaljnyj ekonomichnyj universytet, $699 \mathrm{pp}$.

\title{
УДК 365.04.008
}

\section{СТРАТЕГІЯ УПРАВЛІННЯ СТРУКТУРНИМИ ТРАНСФОРМАЦІЯМИ ІННОВАЦЙННОГО ПОТЕНЦІАЛУ ПРОМИСЛОВИХ ЕНЕРГЕТИЧНИХ ПІДПРИЕМСТВ}

\author{
Проценко А.В., здобувач (УІПА)
}

В статті визначено, щзо управління структурними трансформаціями інноваційного потенціалу $\epsilon$ важливою складовою загальної системи управління діяльністю підприємств.

Зроблено висновок, щзо підвищення якості управління структурними трансформаціями інноваційного потенціалу промислових енергетичних підприємств в процесі адаптації фінансово-економічного розвитку повинне передбачати ефективне впровадження сучасних наукових досягнень у иій сфері діяльності. Таким чином, у процесі генерації стратегії управління структурними трансформачіями інноваційного потениіалу підприємств необхідно враховувати якісні ци кількісні показники, що характеризують результати використання всіх видів ресурсів.

Ключові слова: стратегія управління; структурні трансформації; інноваційний потенціал; ефективність; розвиток. 